Al-Madrasah: Jurnal Ilmiah Pendidikan Madrasah Ibtidaiyah

Vol. 4, No. 2, 2020

DOI $10.35931 / \mathrm{am} . \mathrm{v} 4 \mathrm{i} 2.331$

P-ISSN: 2620-5807; E-ISSN: 2620-7184

\title{
PENGEMBANGAN MEDIA PEMBELAJARAN ARTICULATE STORYLINE KURIKULUM 2013 BERBASIS KOMPETENSI PESERTA DIDIK ABAD 21 TEMA 7 KELAS IV SEKOLAH DASAR
}

\author{
Priankalia Arwanda ${ }^{1}$, Sony Irianto ${ }^{2}$, Ana Andriani ${ }^{3}$ \\ Dosen Universitas Muhammadiyah Purwokerto, Jawa Tengah, Indonesia \\ e-mail: ${ }^{1}$ priankalia@gmail.com, ${ }^{2}$ sonyirianto75@gmail.com, \\ 3ana.andriani@gmail.com
}

\begin{abstract}
This research is based on problems in the school. Problems are found based on observations and analysis of learning media in schools. Learning runs well if in the learning process is supported by adequate supporting facilities and infrastructure, one of which is the use of learning media. The purpose of this study was to produce learning media for the 2013 curriculum Articulate Storyline based on 21st century students competency theme 7 grade IV elementary school. The type of research used is research and development $(R \& D)$ with the $4 D$ model developed by Thiagarajan. Data collection techniques through tests and non-tests. The results of this study indicate that learning media can be used as a support for the learning process. The learning media obtained an average score of 4.23 validator results with a very good predicate. Articulate Storyline learning media theme 7 with TPS (think, pair and square) models can improve $4 C$ competencies (critical thinking and problem solving, creative and innovative, collaborative, and communicative) according to 21st century learning demands. an average of 4.73 with a very good predicate. Student responses to learning media get an average score of 4.6 with a very good predicate.
\end{abstract}

Keywords: Learning media, Articulate Storuline, 2013 Curriculum, Thematic, Elementary School

\section{PENDAHULUAN}

Teknologi merupakan suatu sarana yang dihasilkan dari kebudayaan manusia, berdasarkan inovasi yang dilakukan untuk mempermudah aktivitas masyarakat. Teknologi dikembangkan untuk mempermudah kepentingan manusia di berbagai bidang kehidupan. Teknologi memiliki banyak manfaat bagi manusia. Manfaat tersebut dapat berupa manfaat positif ataupun negatif tergantung dengan manusia yang menggunakannya. Teknologi pada dasarnya 
lebih banyak memiliki manfaat positif, yang hadir untuk kebaikan manusia. Kemajuan teknologi membuat tantangan yang dihadapi manusia semakin meningkat dalam berbagai bidang kehidupan. Tantangan akan dialami oleh setiap individu, mereka akan bersaing untuk mengikuti perkembangan yang ada. Menciptakan peserta didik yang mampu menghadapi tantangan perlu upaya struktural dalam menyiapkan peserta didik dalam menghapi situasi tersebut. Kehidupan bergeser dari konvensional menjadi modern dengan melibatkan teknologi pada setiap kegiatan. Kecakapan hidup yang perlu dipersiapkan untuk menghadapi abad 21 yaitu meliputi tiga aspek literasi dasar, kompetensi dan karakter.

Pendidikan merupakan usaha sadar dan terencana untuk mewujudkan manusia yang berkarakter. Proses pembelajaran dilaksanakan bertujuan untuk membantu peserta didik mengembangkan potensi yang dimiliki, keterampilan, sikap spiritual, memiliki kecerdasan, dapan mengendalikan diri, berakhlak mulia, percaya diri, bertanggungjawab, serta memiliki ketrampilan yang memiliki manfaat baik untuk diri sendiri, agama, masyarakat, bangsa dan negara.

Undang-undang Nomor 20 Tahun 2003 tentang Sistem Pendidikan Nasional menyebutkan bahwa kurikulum adalah seperangkat rencana dan pengaturan mengenai tujuan, isi dan bahan pelajaran serta cara yang digunakan sebagai pedoman penyelenggaraan kegiatan pembelajaran untuk mencapai tujuan pendidikan tertentu. Berdasarkan pengertian tersebut terdapat dua dimensi kurikulum, yang pertama adalah rencana dan pengaturan mengenai tujuan, isi dan bahan pelajaran, sedangkan yang kedua adalah cara yang digunakan untuk kegiatan pembelajaran. Kurikulum tersebut digunakan sebagai pedoman yang digunakan oleh pendidik untuk melakukan proses pembelajaran mulai dari tahap perencanaan. Kurikulum 2013 juga digunakan sebagai pedoman guru dalam tahap pelaksanaan pembelajaran dan evaluasi yang dilakukan pada setiap kegiatan belajar mengajar, untuk mengetahui keberhasilan mencapai tujuan yang telah di buat baik dalam aspek kognitif, afektif, dan psikomotorik. ${ }^{1}$

Studi pendahuluan dilakukan melalui kegiatan observasi dan wawancara terhadap guru kelas IV mengenai media pembelajaran yang digunakan guru di kelas IV. Kegiatan Belajar Mengajar (KBM) di kelas IV SD sudah menggunakan media pembelajaran, tetapi hanya saja dalam pembelajaran tertentu. Hasil analisis media yang telah saya lakukan memiliki beberapa kelemahan, antara lain (1) Media pembelajaran bersifat klasikal atau berlaku

1 Rusman, Pembelajaran Tematik Terpadu: Teori, Praktik, dan Penilaian. (Jakarta: PT RajaGrafindo, Persada2016), h 85. 
untuk satu kelas. (2) Media yang digunakan hanya berupa media power point. (3) Media pembelajaran mencangkup tulisan dan gambar saja. (4) Media pembelajaran yang digunakan oleh guru tidak melibatkan peserta didik. Walaupun dalam pembelajaran sudah menggunakan media pembelajaran, tetapi untuk meningkatkan prestasi belajar dan antusiasme peserta didik dalam menerima materi pembelajaran guru belum mampu menciptakan hal tersebut. Ada beberapa peserta didik yang mendapatkan hasil kurang maksimal, sehingga guru perlu melakukan remidial. Hasil observasi yang telah dilakukan menunjukan bahwa media pembelajaran yang digunakan di SD UPK Kembaran untuk menyampaikan materi pembelajaran belum sesuai dengan standar yang ada. Pembelajaran abad 21 guru harus menggunakan media pembelajaran berbasis teknologi untuk dapat menciptakan kompetensi 4C (Critical thingking and problem solving, creativity, collaborative, and communication) pada peserta didik, sehingga media yang digunakan oleh guru beralih dari media gambar cetak menjadi media berbasis teknologi.

Hasil analisis kebutuhan media pembelajaran yang tersedia, perlu dilakukan pengembangan untuk menarik dan menambah antusias peserta didik dalam mengikuti kegiatan belajar mengajar. Pengembangan media perlu dilakukan agar produk media berpengaruh pada tujuan pembelajaran yang dicapai lebih baik. Media pembelajaran yang dikembangkan berupa media Articulate Storyline. Media ini diharapkan dapat meningkatkan ketertarikan peserta didik dalam mengikuti kegiatan belajar mengajar dan mengasah peserta didik untuk dapat bekerja sama baik dalam kelompok maupun antar kelompok. Media pembelajaran Articulate Storyline merupakan salah satu media pembelajaran yang sengaja dibuat untuk mengemas sebuah pembelajaran. Pemanfaatan Articulate Storyline sebagai media pembelajaran melibatkan peserta didik langsung, sehingga peserta didik akan terlibat aktif dalam pembelajaran. Media pembelajaran yang dikembangakan berupa media e-learning dengan perangkat komputer yang digunakan secara kelasikal. Media pembelajaran mengemas pembelajaran Collaboratif Learning Learning dengan memanfaatkan aplikasi Articulate Storyline berupa multimedia interaktif audiovisual.

\section{Metode Penelitian}

Jenis penelitian yang digunakan adalah R\&D (Research and Development) dengan desai penelitian TPS (Think-Pair-Square) yang dikembangkan oleh Thiagarajan (1974) menjelaskan ada empat tahapan penelitian dan pengemangan yang disingkat dengan 4-D, yaitu "define, design, develop, and disseminate." Tahap define, yaitu tahap studi pendahuluan, baik secara teorik maupun empirik. Tahap design, yaitu 
merancang model dan prosedural pengembangan secara konseptual-teoritik. Tahap develop, yaitu melakukan kajian empirik tentang pengembangan produk awal, melakukan uji coba, revisi dan validasi. Tahap disseminate ${ }^{2}$.

Uji coba produk menggunakan TPS (Think-Pair-Square). Teknik pengumpulan data digunakan dengan non tes yaitu berupa angket dan observasi. Teknik analisis data dilakukan ketika tahap pengumpulan data telah selesai. Analisis data dilakukan dengan menganalisis hasil validasi ahli, angket respon guru, dan angket respon peserta didik.

\section{Hasil dan Pembahasan}

Penelitian dan pengembangan ini menghasilkan produk media pembelajaran Articulate Storyline kurikulum 2013 berbasis kompetensi peserta didik abad 21 tema 7 indahnya keragaman di negeriku subtema 1 pembelajaran 2 kelas IV sekolah dasar. Brigss (Yaumi : 2018) menyatakan bahwa media pembelajaran juga dipandang sebagai peralatan fisik yang digunakan untuk mengirim pesan kepada peserta didik dan menstimulasi mereka unruk belajar. Newby dkk dalam Yaumi ( 2018 : 5) mengemukakan saluran komunikasi adalah alat yang membawa pesan dari seorang individu ke individu lainnya. ${ }^{3}$

Model pembelajaran yang digunakan dalam penerapan media pembelajaran yaitu model pembelajaran kolaboratif (TPS). ${ }^{4}$ Le (2018) menyebutkan bahwa Collaboratif Learning dapat memberikan pengalaman yang lebih kepada peserta didik. ${ }^{5}$ Kolaboratif dapat memberikan pengalaman lebih kepada peserta didik karena dalam sebuah kerja sama antara guru dengan peserta didik pasti akan terjadi transfer ilmu yang dilakukan oleh guru untuk peserta didik, serta adanya pemikiran yang berasal dari banyak orang dalam menyelesaikan sebuah permasalahan. TPS (Think Pair Square) termasuk ke dalam model pembelajaran kolaboratif.

${ }^{2}$ Thiagarajan dkk., Instructional Development for Training Teacher of Exceptional Children: A Sourcebook (Washington, D.C.: National Center for Improvement of Educational Systems (DHEW/ OE)1974).

3 Yaumi, M., Media dan Teknologi Pembelajaran (Jakarta: Prenadamedia Grup2018),h5.

4 Purnamawati., Pengembangan Model Pembelajaran Kolaboratif melalui Pendekatan CSCL (Computer Supported Colabborative Learning) pada Fakultas Teknik Universitas Negeri Makassar. (Jurnal Media Komunikasi Pendidikan Teknologi dan Kejuruan. Vol 3.2016).

${ }^{5}$ Le, H. dkk., Collaborative Learning Practices: Teacher and Student Perceived Obstacles to Effective Student Collaboration. (Cambridge Journal of Education Vol $48.12018)$. 
TPS merupakan modifikasi pembelajaran dari Thing Pair Share. TPS memberikan kesempatan kepada peserta didik untuk berpikir sendiri dan bekerja sama dengan peserta didik lain. Langkah pembelajaran dari TPS mememiliki dasar dari Think Pair Share. Langkah pembelajaran dari TPS mememiliki dasar dari Think Pair Share. Pembelajan dilakukan dengan beberapa langkah yaitu, (1) peserta didik berpikir sendiri untuk mecahkan sebuah permasalahan; (2) peserta didik berdiskusi bersama dengan teman sebangku untuk menyatukan pikiran; (3) peserta didik membuat kelompok terdiri dari empat anggota untuk memecahkan permasalahan yang disajikan guru. Proses pembelajaran dilaksanakan dengan memecahkan permasalahan secara berkelompok, TPS memfasilitasi peserta didik dalam meningkatkan keterampilan kolaboratif (Yaqin : $2018: 136$ ). ${ }^{6}$

Model TPS dapat menciptakan kompetensi peserta didik abad 21 meliputi kompetensi 4C (critical thinking and problem solving, creative and innovative, collaborative and communicative). Greenstein dalam Sugiyarti (2012) menyatakan bahwa peserta didik yang hidup pada abad 21 harus menguasai keilmuan, berketerampilan metakognitif, mampu berpikir kritis dan kreatif, serta bisa berkomunikasi atau berkolaborasi yang efektif, keadaan ini menggambarkan adanya kesenjangan antara harapan dan kenyataan. ${ }^{7}$ Pengembangan media pembelajaran dengan metode penelitian dan pengembangan (R\&D) dengan model 4D yang dikembangkan oleh Thiagarajan. Penelitian ini terdapat empat tahapan yaitu: Define (pendefinisian), Design (desain), Develop (pengembangan), dan Disseminate (penyebaran).

Prilly Nur Indasari (2019) Articulate Storyline dalam tekanan cair untuk kelas 8 yang secara teori layak berdasarkan validitas media. Hasil penelitian menunjukkan bahwa validitas multimedia interaktif mendapat kriteria yang sangat layak. ${ }^{8}$ Dalam aspek format media, persentasenya adalah $92,86 \%$, sedangkan aspek materi dari media memiliki persentase $94,44 \%$. Hasil penelitian menunjukkan bahwa multimedia interaktif berdasarkan Articulate Storyline secara teori layak. Penelitian ini memiliki kesamaan dengan penelitian yang akan dilaksanakan, yaitu pengembangan media pembelajaran Articulate Stotyline. Media pembelajaran yang dikembangkan

6 Yaqin, Mustafa A. dkk., Think-Pair-Square Leraning: Improving Student's Collaborative Skills and Cognitive Learning Outcome on Animal Diversity Course (Jurnal Pendidikan Biologi Indonesia (JPBI). Vol. 4 No. 2 2018),h 136.

7 Sugiyarti, Lina dkk., Pembelajaran Abad 21 di SD(Prosiding Seminar dan Diskusi Nasional Pendidikan Dasar UNJ ISSN:2528-55642018)

8 Indasari, P., Theoretical Feasibility Of Interactive Multimedia Based On Articulate Storyline In Liquid Pressure.(E-Jurnal Pensa. Vol 072019) 
memiliki perbedaan dengan penelitian sebelumnya. Penelitian mengembangkan media pembelajaran IPA materi tekanan pada benda cair, sedangkan media yang dikembangkan pada penelitian ini media pembelajaran tematik. Pengembangan media ini diharapkan berhasil seperti pengembangan mediayang dilaksanakan sebelumnya.

Ha Le, Jeroen Janssen \& Theo Wubbels (2019) kerasama antara guru dan peserta didik dengan model pembelajaran kolaboratif yang saat ini masih belum dilakukan secara maksimal karena guru cenderung menekankan pada aspek kognitif. ${ }^{9}$ Penelitian ini bermula dengan survei di beberapa Sekolah Dasar di Vietnam. Subjek penelitian dilakukan kepada 19 guru dan 23 peserta didik. Metode penelitian ini adalah metode kuantitatif. Adapun teknik analisis data dengan menggunakan wawancara. Penggunaan Collaborative Learning antara guru dengan peserta didik dapat meningkatkan kualitas pembelajaran secara signifikandari data yang diperoleh meningkat dari $57 \%$ menjadi 78\%. Pembelajaran kolaboratif akan digunakan dalam uji coba media pembelajaran yang telah dikembangkan, metode tersebut diharapkan dapat menciptakan kompetensi peserta didik abad 21.

Genc Osman Ilhan \& Sahin Oruc, (2016) menguraikan tentang pengaruh multimedia untuk peserta didik. ${ }^{10}$ Metode penelitian ini mengacu pada model pengembangan eksperimental. Subjek penelitian yaitu peserta didik kelas IV dan kelas VIII. Hasil penelitian menyebutkan bahwa perbedaan antara kelas kontrol dengan kelas eksperimen memiliki perbedaan yang signifikan. Pembuktian berdasarkan hasil uji SPSS, multimedia teknik memiliki perbedaan yang cukup signifikan dengan teknik tradisional. Penelitian ini memiliki kesamaan dengan penelitian yang akan dilaksanakan yaitu dengan adanya pengembangan media pembelajaran Articulate Storyline yang termasuk multimedia interaktif yang diharapkan dapat meciptakan pembelajaran abad 21 dengan pemanfaatan teknologi dalam kegiatan pembelajaran.

\section{Hasil validasi ahli kelayakan media pembelajaran}

Kegiatan validasi dilakukan oleh validator yang memiliki keahlian dalam bidang masing-masing. Validasi ahli dilakukan oleh tiga validator yaitu validasi ahli media dilakukan oleh dua validator dan validasi bahasa dan materi

${ }^{9}$ Le, H. dkk., Collaborative Learning Practices: Teacher and Student Perceived Obstacles to Effective Student Collaboration. ( Cambridge Journal of Education Vol $48.12018)$

${ }^{10}$ Ilhan, G.\& Sahin O., Effect of the Use of Multimedia on Students' Performance: A Case Study of Social Studies Class. (Academic Journal Vol 11.8 2016) 
dilakukan oleh satu validator ahli. Hasil validasi digunakan sebagai saran untuk melakukan perbaikan media pembelajaran yang telah dikembangkan.

Tabel 4.1 Tabel Rekapitulasi Hasil Validasi

\begin{tabular}{|l|l|l|l|l|c|}
\hline No & \multicolumn{1}{|c|}{ Ahli } & Validasi & $\begin{array}{c}\text { jumlah } \\
\text { rata-rata }\end{array}$ & $\begin{array}{c}\text { Rata- } \\
\text { rata }\end{array}$ & $\begin{array}{c}\text { Rata-rata } \\
\text { nilai score }\end{array}$ \\
\cline { 1 - 5 } 1. & Materi dan bahasa & 1 & 13 & 4,33 & \multirow{2}{*}{4,23} \\
\cline { 1 - 4 } 2. & Media 1 & 1 & 8,05 & 4,025 & \multirow{2}{*}{} \\
\cline { 1 - 4 } & Media 1 & 2 & 9 & 4,5 & \\
\hline
\end{tabular}

Hasil validasi yang telah dilakukan oleh tiga validasi ahli menunjukan rata-rata nilai score 4,23 yang artinya sangat baik. Nilai didapatkan dengan melihat rentang score dalam tabel validasi ahli 4,2 sampai dengan atau kurang dari 5,0 demikian menunjukan pengembangan media pembelajaran sangat baik. Pengembangan media pembelajaran tidaklah cukup dengan mendapatkan nilai, tetapi dilengkapi dengan saran yang harus dipenuhi oleh pengembang untuk mencapai pengembangan media pembelajaran yang diharapkan oleh validator ahli.

\section{Penerapan media pembelajaran}

Uji coba produk dilakukan setelah media pembelajaran melalui tahap revisi untuk diuji cobakan dalam pembelajaran. Uji coba media pembelajaran dilakukan dengan cara uji coba terbatas sesuai dengan langkah sesuai dengan model pembelajaran TPS (think-pair-square). Uji coba dilaksanakan setelah mendapatkan nilai validasi ahli sehingga produk layak digunakan dalam penelitian. Uji coba terbatas dilaksanakan di SD Negeri Kembaran. uji coba bertujuan untuk mendapatkan respon guru dan peserta didik mengenai penggunaan media pembelajaran yang telah dikembangkan untuk proses pembelajaran dalam mencapai tujuan pembelajaran. Setelah uji coba produk terbatas dilaksanakan di SD Negeri Kembaran dapat diperoleh hasil respon positif dari guru dan peserta didik. Respon yang diberikan terhadap media pembelajaran yang digunakan dalam proses pembelajaran sesuai dengan pembelajaran abad 21 untuk mencapai kompetensi peserta didik abad 21 dengan model TPS yang dapat melatih kopetensi peserta didik secara mandiri dan berkelompok dalam berpikir kritis dan memecahkan masalah, kreatif dan inovatif, bekerja sama dan berkomunikasi dengan baik.

\section{Respon Guru Terhadap Media Pembelajaran Articulate Storyline}

Angket respon guru digunakan untuk mengetahui tanggapan guru terhadap media pembelajaran yang telah dikembangkan. Penilaian media 
pembelajaran dilakukan oleh guru kelas IV SD Negeri Kembaran. Penilaian dilaksanakan setelah kegiatan uji coba media Articulate Storyline melalui kegiatan pembelajaran.

\section{Tabel 4.3 Hasil Respon Guru Terhadap Media Pembelajaran}

Tabel 4.3 Hasil Respon Guru terhadap Media Pembelajaran dapat disimpulkan bahwa penilaian guru terhadap media pembelajaran yang telah dikembangkan mendapatkan rata-rata nilai total 4,73 dengan kriteria sangat baik. Kriteria penilaian guru didapatkan dari penilaian guru yang memiliki rentang nilai 4,2 sampai kurang dari atau sama dengan 5,0. Penilaian guru juga dilengkapi dengan saran dan masukan untuk mengasilkan produk pengembangan yang lebih baik.

\section{Respon Peserta Didik Terhadap Media Articulate Storyline}

Angket respon peserta didik di isi oleh 30 peserta didik kelas IV SD Negeri Kembaran. Angket respon peserta didik bertujuan untuk mendapatkan hasil penilaian terhadap media pembelajaran yang telah dikembangkan.

\subsection{Tabel Respon Peserta Didik Terhadap Media Pembelajaran}

\begin{tabular}{|l|l|c|c|c|c|c|c|c|c|c|c|}
\hline \multirow{2}{*}{ No } & \multicolumn{2}{|c|}{ Nama } & \multicolumn{7}{|c|}{ Perrnyataan- } & $\begin{array}{c}\text { Rata- } \\
\text { rah }\end{array}$ \\
\cline { 2 - 12 } & 1 & 2 & 3 & 4 & 5 & 6 & 7 & 8 & lah & Dwi \\
\hline 1 & $\begin{array}{l}\text { Suci Dahmadani } \\
\text { Rahming }\end{array}$ & 5 & 4 & 5 & 4 & 5 & 5 & 4 & 5 & 37 & 4,625 \\
\hline
\end{tabular}

\begin{tabular}{|c|c|c|c|c|c|}
\hline No & Aspek & $\begin{array}{c}\text { Nomor } \\
\text { Pernyataan } \\
\end{array}$ & $\begin{array}{c}\text { Skor Respon } \\
\text { Guru }\end{array}$ & $\begin{array}{l}\text { Nilai } \\
\text { Total } \\
\end{array}$ & $\begin{array}{c}\text { Rata-rata } \\
\text { Total }\end{array}$ \\
\hline \multirow[t]{5}{*}{1} & \multirow{5}{*}{$\begin{array}{l}\text { Materi media } \\
\text { pembelajaran }\end{array}$} & $\mathrm{a}$ & 5 & \multirow{5}{*}{30} & \multirow{5}{*}{ 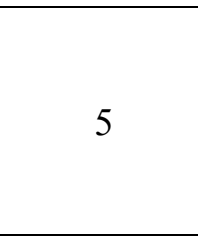 } \\
\hline & & $\mathrm{b}$ & 5 & & \\
\hline & & $\mathrm{c}$ & 5 & & \\
\hline & & $\mathrm{d}$ & 5 & & \\
\hline & & $\mathrm{e}$ & 5 & & \\
\hline \multirow[t]{3}{*}{2} & \multirow{3}{*}{$\begin{array}{l}\text { Komunikasi } \\
\text { visual }\end{array}$} & $\mathrm{a}$ & 5 & \multirow{3}{*}{14} & \multirow{3}{*}{4,6} \\
\hline & & $\mathrm{b}$ & 5 & & \\
\hline & & $\mathrm{c}$ & 4 & & \\
\hline \multirow[t]{6}{*}{3} & \multirow[t]{6}{*}{ Kebahasaan } & $\mathrm{a}$ & 5 & \multirow{6}{*}{28} & \multirow{6}{*}{4,6} \\
\hline & & $\mathrm{b}$ & 5 & & \\
\hline & & $\mathrm{c}$ & 5 & & \\
\hline & & $\mathrm{d}$ & 5 & & \\
\hline & & $\mathrm{e}$ & 4 & & \\
\hline & & $\mathrm{f}$ & 4 & & \\
\hline \multicolumn{5}{|c|}{ Jumlah } & 14,2 \\
\hline \multicolumn{5}{|c|}{ Rata-rata } & 4,73 \\
\hline \multicolumn{5}{|c|}{ Kriteria } & Sangat Baik \\
\hline
\end{tabular}


Priankalia Arwanda, Sony Irianto, Ana Andriani: Pengembangan Media Pembelajaran Articulate Storyline Kurikulum 2013 Berbasis Kompetensi Peserta Didik Abad 21 Tema 7 Kelas IV Sekolah Dasar

\begin{tabular}{|l|l|c|c|c|c|c|c|c|c|c|c|}
\hline 2 & $\begin{array}{l}\text { Desi Dewi } \\
\text { Mulyani }\end{array}$ & 5 & 5 & 4 & 5 & 5 & 5 & 5 & 4 & 38 & 4,75 \\
\hline 3 & $\begin{array}{l}\text { Faisal } \\
\text { Firmansyah }\end{array}$ & 5 & 4 & 5 & 4 & 5 & 4 & 5 & 4 & 36 & 4,5 \\
\hline 4 & $\begin{array}{l}\text { Agustina } \\
\text { Lestari }\end{array}$ & 4 & 5 & 4 & 5 & 4 & 5 & 4 & 5 & 36 & 4,5 \\
\hline 5 & Akbar Fauzi & 5 & 5 & 5 & 4 & 4 & 4 & 5 & 4 & 36 & 4,5 \\
\hline 6 & Aldi Setiawan & 5 & 5 & 4 & 4 & 5 & 5 & 4 & 5 & 37 & 4,625 \\
\hline 7 & $\begin{array}{l}\text { Anggi } \\
\text { Kurniawan }\end{array}$ & 4 & 4 & 5 & 5 & 4 & 5 & 4 & 5 & 36 & 4,5 \\
\hline 8 & $\begin{array}{l}\text { Anugrah } \\
\text { Naafi A. }\end{array}$ & 5 & 4 & 5 & 4 & 5 & 5 & 5 & 5 & 38 & 4,75 \\
\hline 9 & $\begin{array}{l}\text { Dewi } \\
\text { Kusumawati }\end{array}$ & 4 & 5 & 5 & 5 & 5 & 4 & 5 & 5 & 38 & 4,75 \\
\hline 10 & $\begin{array}{l}\text { Farij Anggi } \\
\text { Permana }\end{array}$ & 5 & 5 & 4 & 5 & 4 & 5 & 5 & 4 & 37 & 4,625 \\
\hline 11 & $\begin{array}{l}\text { Fariz Reza } \\
\text { Saputra }\end{array}$ & 5 & 5 & 4 & 5 & 4 & 5 & 5 & 4 & 37 & 4,625 \\
\hline 12 & $\begin{array}{l}\text { Fathma Nur } \\
\text { Ammni }\end{array}$ & 5 & 5 & 5 & 5 & 5 & 5 & 5 & 5 & 40 & 5 \\
\hline 13 & $\begin{array}{l}\text { Fauzan } \\
\text { Pratama }\end{array}$ & 5 & 5 & 5 & 5 & 5 & 5 & 5 & 5 & 40 & 5 \\
\hline 14 & $\begin{array}{l}\text { Firda Nur } \\
\text { Azizah }\end{array}$ & 4 & 5 & 5 & 5 & 5 & 5 & 5 & 5 & 39 & 4,875 \\
\hline 15 & $\begin{array}{l}\text { Junita } \\
\text { Anindia K. D. }\end{array}$ & 5 & 4 & 5 & 5 & 5 & 4 & 5 & 4 & 37 & 4,625 \\
\hline 16 & $\begin{array}{l}\text { Kholifa } \\
\text { Umairach }\end{array}$ & 5 & 5 & 5 & 5 & 5 & 5 & 5 & 5 & 40 & 5 \\
\hline 17 & $\begin{array}{l}\text { Lyana Hilmi } \\
\text { Naila } \\
\text { Safinatun } \\
\text { Naja }\end{array}$ & 4 & 5 & 5 & 4 & 5 & 5 & 5 & 5 & 38 & 4,75 \\
\hline 19 & $\begin{array}{l}\text { Naila Nur } \\
\text { Khasanah }\end{array}$ & 5 & 4 & 5 & 4 & 5 & 4 & 5 & 4 & 36 & 4,5 \\
\hline 20 & $\begin{array}{l}\text { Raihan Eka } \\
\text { Saputra }\end{array}$ & 5 & 4 & 5 & 5 & 4 & 5 & 4 & 5 & 37 & 4,625 \\
\hline 21 & $\begin{array}{l}\text { Rizki Dwi } \\
\text { Saputro }\end{array}$ & 5 & 4 & 4 & 5 & 4 & 5 & 4 & 5 & 36 & 4,5 \\
\hline 22 & $\begin{array}{l}\text { Sugeng } \\
\text { Triyono }\end{array}$ & 5 & 5 & 4 & 5 & 4 & 5 & 4 & 5 & 37 & 4,625 \\
\hline & 5 & 5 & 4 & 35 & 4,375 \\
\hline 18 & & & & & \\
\hline
\end{tabular}

Al-Madrasah: Jurnal Ilmiah Pendidikan Madrasah Ibtidaiyah Vol. 4, No. 2, Januari-Juni 2020 
Priankalia Arwanda, Sony Irianto, Ana Andriani: Pengembangan Media Pembelajaran Articulate Storyline Kurikulum 2013 Berbasis Kompetensi Peserta Didik Abad 21 Tema 7 Kelas IV Sekolah Dasar

\begin{tabular}{|c|c|c|c|c|c|c|c|c|c|c|c|}
\hline 23 & $\begin{array}{ll}\text { Syalia } & \text { Asfa } \\
\text { Nesha } & \\
\end{array}$ & 5 & 5 & 4 & 5 & 5 & 4 & 5 & 5 & 38 & 4,75 \\
\hline 24 & $\begin{array}{l}\text { Syehfa } \\
\text { Ustajaah }\end{array}$ & 4 & 5 & 5 & 4 & 5 & 4 & 5 & 5 & 37 & 4,625 \\
\hline 25 & $\begin{array}{ll}\text { Tania } & \text { Putri } \\
\text { Andini } & \\
\end{array}$ & 5 & 4 & 5 & 5 & 5 & 5 & 5 & 4 & 38 & 4,75 \\
\hline 26 & $\begin{array}{ll}\text { Valen } & \text { Aulia } \\
\text { Sari } & \\
\end{array}$ & 4 & 5 & 5 & 4 & 5 & 5 & 4 & 5 & 37 & 4,625 \\
\hline 27 & $\begin{array}{l}\text { Vicky } \\
\text { Aldiansyah }\end{array}$ & 5 & 5 & 5 & 5 & 5 & 5 & 5 & 5 & 40 & 5 \\
\hline 28 & $\begin{array}{l}\text { Vilova } \\
\text { Damarratu A. }\end{array}$ & 4 & 5 & 5 & 5 & 4 & 5 & 5 & 5 & 38 & 4,75 \\
\hline 29 & $\begin{array}{l}\text { Nailul } \\
\text { Mubarok }\end{array}$ & 4 & 4 & 5 & 5 & 4 & 5 & 4 & 5 & 36 & 4,5 \\
\hline 30 & $\begin{array}{l}\text { Azka Arayan } \\
\text { P. }\end{array}$ & 5 & 4 & 4 & 5 & 5 & 4 & 4 & 5 & 36 & 4,5 \\
\hline \multicolumn{11}{|c|}{ Jumlah } & 140,125 \\
\hline \multicolumn{11}{|c|}{ Rata-rata } & 4,6 \\
\hline \multicolumn{11}{|c|}{ Kriteria } & $\begin{array}{l}\text { Sangat } \\
\text { Baik }\end{array}$ \\
\hline
\end{tabular}

Hasil respon peserta didik terhadap media pembelajaran dapat disimpulkan bahwa respon peserta didik mendapatkan nilai rata-rata 4,6 dengan kriteria sangat baik. Kriteria sangat baik didapatkan dari rentang nilai respon peserta didik 4,2 sampai kurang dari atau sama dengan 5.0. Pengembangan media pembelajaran sangat baik juga ditunjukan pada uji coba media pembelajaran minat peserta didik dalam mengikuti pembelajaran tinggi. Peserta didik aktif dalam kegiatan pembelajaran dari awal kegiatan hingga akhir pembelajaran.

\section{Kesimpulan}

Hasil penelitian dan pembahasan data dapat dijadikan sebagai acuan untuk mengambil kesimpulan dari penelitian Pengembangan Media Pembelajaran Articulate Storyline Kurikulum 2013 Berbasis Kompetensi Peserta Didik Abad 21 Tema 7Kelas IV Sekolah Dasar memiliki kondisi awal media pembelajaran kelas IV Sekolah Dasar Negeri Kembaran masih terbatas. Media pembelajaran masih belum sesuai dengan kompetensi peserta didik abad 21 yaitu meliputi kompetensi 4C (Critical thinking and problem solving, Creative and innovative, Collaborative and Comunicative).

Pengembangan media pembelajaran Articulate Storyline kurikulum 2013 berbasis kompetensi peserta didik abad 21 tema 7 indahnya keragaman 
di negeriku subtema 1 pembelajaran 2 Kelas IV Sekolah Dasar dapat digunakan dalam proses pembelajaran.

Validasi ahli media pembelajaran dilakukan oleh tiga orang ahli. Perolehan nilai dari masing-masing ahli yaitu ahli materi dan bahasa validasi sebanyak 1 kali dengan nilai rata-rata 4,33, ahli media 1 sebanyak 2 kali dengan nilai rata-rata 4,025 dan 4,5 , dan ahli media 2 sebanyak 1 kali dengan nilai rata-rata sebanyak 4,08. Rekapitulasi nilai score rata-rata yaitu 4,23 dengan predikat sangat baik. Predikat sangat baik didapatkan karena nilai berada pada rentang 4,2 sampai dengan atau kurang dari 5,0.

Respon guru kelas IV SD Negeri Kembaran terhadap pengembangan media pembelajaran Hasil respon guru terhadap media pembelajaran yaitu dengan nilai 4,73 yang mendapat predikat sangat baik. Predikat didapatkan dari rentang nilai respon guru 4,2 sampai dengan atau kurang dari 5,0.

Respon peserta didik kelas IV SD Negeri Kembaran terhadap pengembangan media pembelajaran. Hasil respon peserta didik terhadap media pembelajaran yaitu dengan nilai 4,6 yang mendapat predikat sangat baik. Predikat didapatkan dari rentang nilai respon peserta didik 4,2 sampai dengan atau kurang dari 5,0.

\section{Saran}

Pengembangan media pembelajaran yang telah dilaksanakan tentu saja tidak dapat mencapai kesempurnaan. Penelitian memProduk media pembalajaran articulate storyline memiliki sintaks yang mengacu pada kompetensi abad 21 yang lebih banyak memerlukan waktu, sehingga dalam mengemas pembelajaran yang menggunakan media tersebut untuk lebih membagi waktu dengan tepat. Penerapan pembelajaran abad 21 memiliki kesulitan dan tuntutan baik bagi guru maupun peserta didik. Guru harus memiliki pemahaman terhadap pembelajaran abad 21 untuk mencapai kompetensi peserta didik abad 21. peserta didik dituntut untuk lebih aktif berdiskusi dan memiliki kompetensi peserta didik abad 21 meliputi 4C. Pengembangan media pembelajaran yang diharapkan yaitu guru mampu mengembangkan media pembelajaran yang menarik dan efektif dalam mendukung proses pembelajaran sesuai dengan materi yang diterapkan. 
Priankalia Arwanda, Sony Irianto, Ana Andriani: Pengembangan Media Pembelajaran Articulate Storyline Kurikulum 2013 Berbasis Kompetensi Peserta Didik Abad 21 Tema

7 Kelas IV Sekolah Dasar

\section{Daftar Pustaka}

Ilhan, G.\& Sahin O. (2016). Effect of the Use of Multimedia on Students' Performance: A Case Study of Social Studies Class. Academic Journal Vol 11.8 9 Januari 2019

Indasari, P. (2019). Theoretical Feasibility Of Interactive Multimedia Based On Articulate Storyline In Liquid Pressure. E-Jurnal Pensa. Vol 07.1 Desember 2019.

Le, H. dkk. (2018). Collaborative Learning Practices: Teacher and Student Perceived Obstacles to Effective Student Collaboration. Cambridge Journal of Education Vol 48.19 Januari 2020

Purnamawati. (2016). Pengembangan Model Pembelajaran Kolaboratif melalui Pendekatan CSCL (Computer Supported Colabborative Learning) pada Fakultas Teknik Universitas Negeri Makassar. Jurnal Media Komunikasi Pendidikan Teknologi dan Kejuruan. Vol 3. 1 Desember 2019.

Rusman. (2015). Pembelajaran Tematik Terpadu: Teori, Praktik, dan Penilaian. Jakarta: PT RajaGrafindo Persada.

Sanjaya, Wina. (2012). Media Komunikasi Pembelajaran. Jakarta: Kencana

Sugiyarti, Lina dkk. (2018). Pembelajaran Abad 21 di SD. Prosiding Seminar dan Diskusi Nasional Pendidikan Dasar UNJ 2018. ISSN:2528-5564.

Thiagarajan dkk. (1974). Instructional Development for Training Teacher of Exceptional Children: A Sourcebook. National Center for Improvement of Educational Systems (DHEW/ OE), Washington, D.C.

Yaqin, Mustafa A. dkk. (2018). Think-Pair-Square Leraning: Improving Student's Collaborative Skills and Cognitive Learning Outcome on Animal Diversity Course. Jurnal Pendidikan Biologi Indonesia (JPBI). Vol. 4 No. 2. 26 Januari 2020.

Yaumi, M. (2018). Media dan Teknologi Pembelajaran. Jakarta: Prenadamedia Grup.

Al-Madrasah: Jurnal Ilmiah Pendidikan Madrasah Ibtidaiyah Vol. 4, No. 2, Januari-Juni 2020 